POSSIBILIDADES E DESAFIOS DO PIBID PARA O ESTREITAMENTO DA RELAÇÃO ENTRE ESCOLA E UNIVERSIDADE

\author{
POSIBILIDADES Y DESAFÍOS DEL PIBID PARA FORTALECER LA RELACIÓN \\ ENTRE LA ESCUELA Y LA UNIVERSIDAD
}
POSSIBILITIES AND CHALLENGES OF PIBID TO THE NARROWING OF THE RELATIONSHIP BETWEEN SCHOOL AND UNIVERSITY

\author{
Natalia Neves Macedo DEIMLING ${ }^{1}$ \\ Aline Maria de Medeiros Rodrigues REALI ${ }^{2}$
}

RESUMO: Neste artigo temos por objetivo analisar de que maneira as orientações do Programa Institucional de Bolsa de Iniciação à Docência têm sido desenvolvidas e interpretadas por diferentes sujeitos que compõem o Programa na relação entre as escolas de educação básica e a universidade. Para essa análise foram realizadas entrevistas com 18 professores (entre coordenadores, colaboradores e supervisores) e 48 estudantes bolsistas de quatro subprojetos do PIBID de uma universidade federal brasileira entre os anos de 2013 e 2014. Entre outros aspectos, os resultados mostram que o Programa favorece a aproximação entre escola e universidade e contribui para a desmistificação da concepção de superioridade de uma sobre a outra. Todavia, alguns aspectos foram apontados como limitantes, tais como o pouco apoio da universidade às atividades realizadas e a falta de formação e de apoio das redes de ensino aos supervisores para o planejamento e orientação dos estudantes bolsistas.

PALAVRAS-CHAVE: Formação de professores. Programa de iniciação à docência. Integração escola-universidade.

RESUMEN: En este artículo pretendemos analizar cómo las pautas del Programa Institucional de Iniciación para la Enseñanza han sido desarrolladas e interpretadas por diferentes sujetos que conforman el Programa en la relación entre las escuelas de educación básica y la universidad. Para este análisis, se realizaron entrevistas con 18 profesores (incluidos coordinadores, colaboradores y supervisores) y 48 estudiantes becados de cuatro subproyectos PIBID de una universidad federal brasileña entre los años 2013 y 2014. Entre otros aspectos, los resultados muestran que el Programa favorece la aproximación entre la escuela y la universidad y contribuye a desmitificar la concepción de superioridad de uno sobre el otro. Sin embargo, algunos aspectos se señalaron como limitantes, como el poco apoyo de la universidad a las actividades realizadas y la falta de capacitación y apoyo de las redes educativas a los supervisores para la planificación y orientación de los estudiantes becados.

\footnotetext{
${ }^{1}$ Universidade Tecnológica Federal do Paraná (UTFPR), Campo Mourão - PR - Brasil. Professora Adjunta do Departamento Acadêmico de Química. Doutorado em Educação (UFSCAR). ORCID: https://orcid.org/00000001-8394-3132.E-mail: natanema@gmail.com

${ }^{2}$ Universidade Federal de São Carlos (UFSCAR), São Carlos - SP - Brasil. Professora Titular do Departamento de Teorias e Práticas Pedagógicas. Doutorado em Psicologia (Psicologia Experimental) (USP). ORCID: https://orcid.org/0000-0003-4915-8127. E-mail: alinereali@gmail.com
}

RIAEE - Revista Ibero-Americana de Estudos em Educação, Araraquara, v. 16, n. 4, p. 2509-2538, out./dez. 2021. e-ISSN: 1982-5587 
PALABRAS CLAVE: Formación docente. Programa de iniciación docente. Integración escuela-universidad.

ABSTRACT: In this article we present an analysis of the influences of Institutional Scholarship Initiative Program in the narrowing of the relation between school and university. For this analysis, interviews were conducted with 18 teachers (between coordinators, collaborators, and supervisors) and 48 scholarship students from four PIBID subprojects of a Brazilian federal university between the years of 2013 and 2014. For the analysis and discussion of the data we used the techniques of triangulation and creation of analysis categories. Among other aspects, the results show that the Program has favoured the approach between school and university and contributed to the demystification of the conception of superiority of one over the other. However, some aspects were pointed out as limiting, such as the university's lack of support for the activities carried out and the lack of training and support from the teaching networks to the supervisors for the planning and orientation of the scholarship students.

KEYWORDS: Teacher training. Teaching initiation program. School-university integration.

\section{Considerações iniciais}

O Programa Institucional de Bolsa de Iniciação à Docência (PIBID), articulado à Política Nacional de Formação Docente no Brasil, foi disposto no âmbito do Ministério da Educação (MEC), da Coordenação de Aperfeiçoamento de Pessoal de Nível Superior (CAPES) e do Fundo Nacional de Desenvolvimento da Educação (FNDE) pela Portaria Normativa $\mathrm{n}^{\mathrm{o}} 38$, de 12 de dezembro de 2007, e regulamentado pelo Decreto $\mathrm{n}^{0} 7.219$, de 24 de junho de 2010. Em conformidade com a Portaria $n^{\circ} 259$, de 17 dezembro de 2019 (BRASIL, 2019), o PIBID concede bolsas tanto para alunos que estejam regularmente matriculados em cursos de licenciatura e que tenham concluído até $60 \%$ da carga horária do curso de licenciatura ao ingressar no $\operatorname{programa}^{3}$, como para coordenadores e supervisores responsáveis pelo desenvolvimento do projeto, com auxílios para despesas a ele vinculadas. Trata-se de um Programa composto por diversos sujeitos que, com papéis e responsabilidades diferentes, trabalham para o alcance dos objetivos de formação. Cada Instituição de Ensino Superior (IES) pode submeter apenas um projeto institucional do qual partem todos os subprojetos de área. Para cada projeto é concedida apenas uma bolsa de coordenação institucional pela Capes. O coordenador institucional é o professor da Instituição de Ensino

\footnotetext{
${ }^{3}$ Além dessas exigências, para ingressar no Programa o estudante precisa ter sido aprovado em processo seletivo realizado pela instituição, ter bom desempenho acadêmico, dedicar-se às atividades do PIBID, observando a carga horária mínima de 30 horas mensais e firmar termo de compromisso por meio de sistema eletrônico próprio da Capes (BRASIL, 2019).
}

RIAEE - Revista Ibero-Americana de Estudos em Educação, Araraquara, v. 16, n. 4, p. 2509-2538, out./dez. 2021. e-ISSN: 1982-5587 
Superior (IES) responsável perante a Capes pelo acompanhamento, organização e execução das atividades de iniciação à docência previstas no projeto da instituição, e o coordenador de área é o professor de licenciatura que deve responder pela coordenação do subprojeto de área (sendo um coordenador de área para cada subprojeto) perante a coordenação institucional da IES, bem como elaborar, desenvolver e acompanhar as atividades previstas no subprojeto. O professor supervisor é um docente da escola pública que, integrado ao subprojeto de área, recebe os bolsistas de iniciação à docência, estudantes da licenciatura, a fím de acompanhálos e supervisioná-los em suas atividades na escola.

Segundo dados publicados a partir de março de 2014, 284 Instituições de Educação Superior de todo o país passaram a participar do PIBID desenvolvendo 313 projetos de iniciação à docência em mais de cinco mil escolas públicas de educação básica. Em 2016, o número de bolsas ativas no Programa alcançou o total de 72.057 - 58.055 para alunos de licenciatura, 9.019 para professores da educação básica e 4.983 para professores dos cursos de licenciatura (BRASIL, 2018).

Recentemente o PIBID passou por reformulação, tendo sido regulamentado pela Portaria Gab no 45, de 12 de março de 2018 (BRASIL, 2018), em regime de colaboração, juntamente ao Programa de Residência Pedagógica, outro programa de complementação de formação proposta pelo MEC para os cursos de licenciatura. Em 2019, esta Portaria foi revogada, passando a Portaria $\mathrm{n}^{\mathrm{o}}$ 259, de 17 dezembro de 2019 (BRASIL, 2019), a regulamentar o PIBID, mantendo o regime de colaboração entre os programas.

De acordo com o Decreto ${ }^{0} 7.219 / 2010$, o PIBID tem como objetivos:

I - incentivar a formação de docentes em nível superior para a educação básica; II - contribuir para a valorização do magistério; III - elevar a qualidade da formação inicial de professores nos cursos de licenciatura, promovendo a integração entre educação superior e educação básica; IV - inserir os licenciandos no cotidiano de escolas da rede pública de educação, proporcionando-lhes oportunidades de criação e participação em experiências metodológicas, tecnológicas e práticas docentes de caráter inovador e interdisciplinar que busquem a superação de problemas identificados no processo de ensino-aprendizagem; V - incentivar escolas públicas de educação básica, mobilizando seus professores como coformadores dos futuros docentes e tornando-as protagonistas nos processos de formação inicial para o magistério; VI - contribuir para a articulação entre teoria e prática necessárias à formação dos docentes, elevando a qualidade das ações acadêmicas nos cursos de licenciatura (BRASIL, 2010, p. 4, grifos nossos).

Apesar de o PIBID se configurar como uma das soluções emergenciais acionadas pelo governo federal para tentar suprir a carência de professores da educação básica e manter os 
estudantes nas licenciaturas, não podemos desconsiderar a importância de algumas das metas traçadas por esse programa e suas possibilidades de viabilização em termos de formação docente, especialmente num período de crise estrutural da sociedade que tem cada vez mais se agravado com a atual conjuntura política, atacando de frente a educação brasileira em suas diferentes dimensões. Considerando esses aspectos, e visando ampliar e contribuir com as investigações que têm sido realizadas nos últimos anos sobre a importância e validade social e educacional desse Programa, cumpre-nos realizar uma análise sobre os impactos do PIBID na relação entre a universidade e a escola, sob a ótica daqueles que compõem o Programa. Assim, temos como objetivo nesse artigo analisar a interlocução entre a universidade e as escolas públicas a partir das experiências proporcionadas pelo PIBID, tendo em vista a discussão sobre as influências dessa Programa na relação entre escola e universidade na perspectiva de sujeitos que dele participam.

Trata-se de uma das categorias de análise discutidas em uma pesquisa de abordagem qualitativa que teve na análise documental e na entrevista semiestruturada os principais instrumentos de construção dos dados e na triangulação e categorização ${ }^{4}$ as técnicas de análise dos dados (LÜDKE; ANDRÉ, 2014). As entrevistas analisadas foram realizadas com um coordenador institucional, dois coordenadores de área de gestão de processos educacionais, quatro coordenadores de área, quatro professores colaboradores, sete professores supervisores e 48 alunos bolsistas de quatro subprojetos do PIBID de uma universidade federal brasileira localizada na região Sul do Brasil nos anos de 2013 e 2014 ${ }^{5}$. A escolha por essa instituição se deu pelo fato de ela ser multicampi, abrangendo todas as regiões do estado em que se encontra localizada, bem como por sua adesão ao Programa por parte de todos os cursos de Licenciatura ofertados. Além disso, essa escolha se deu pela facilidade e disponibilidade de contato com seus os professores e estudantes.

São oferecidos pela universidade em questão 17 cursos de licenciatura em todos os seus campi. São eles: Licenciatura em Química (5 campi), Licenciatura em Matemática (4 campi), Licenciatura em Física (1 campus), Licenciatura em Informática (1 campus), Licenciatura em Letras - Português (1 campus) Licenciatura em Letras - Inglês (1 campus) Licenciatura em Letras Português - Inglês (1 campus) e Licenciatura em Ciências Biológicas

\footnotetext{
${ }^{4}$ Com base em uma analogia, na qual múltiplas leituras são tomadas para aumentar a precisão das respostas obtidas, a triangulação na análise envolve a comparação dos dados obtidos por meio das diferentes fontes. Analisando os dados deste modo, foi possível obter perspectivas diferentes sobre o assunto investigado. A partir da triangulação, é possível criar um conjunto de categorias de análise (LÜDKE; ANDRÉ, 2014).

${ }^{5}$ Neste estudo as abordagens e os instrumentos metodológicos utilizados obedeceram aos procedimentos éticos estabelecidos para a pesquisa científica em Ciências Humanas e foram aprovados por um Comitê de Ética em Pesquisa com Seres Humanos.
}

RIAEE - Revista Ibero-Americana de Estudos em Educação, Araraquara, v. 16, n. 4, p. 2509-2538, out./dez. 2021. e-ISSN: 1982-5587 
(3 campi). Como podemos observar, apesar de abranger todas as grandes áreas do conhecimento, a maioria dos cursos de licenciatura contempla a área de ciências exatas.

No ano de 2009, num momento em que alguns cursos de licenciatura se consolidavam e outros eram criados, a instituição enviou uma proposta de Projeto Institucional à Capes tendo em vista aderir ao PIBID. Em 2010, ano de início do PIBID na universidade analisada, o Programa contava com 125 bolsas de iniciação à docência, as quais foram ampliadas para 195 em 2011 e para 261 nos anos de 2012/2013. Até o ano de 2014, 10 campi da instituição participavam do PIBID com 18 subprojetos aprovados. De acordo com dados disponíveis no sítio eletrônico da Capes, foram concedidas à Instituição, no ano de 2014, 433 bolsas de iniciação à docência, 71 bolsas de supervisão, 35 bolsas de coordenação de área, quatro bolsas de Coordenação de área de gestão de processos educacionais e uma bolsa de coordenação institucional.

Os subprojetos têm atividades diferenciadas, dadas as especificidades de cada contexto e área de formação, mas todos se encontram vinculados ao projeto institucional. $\mathrm{Na}$ impossibilidade de abarcar todos os subprojetos do PIBID da universidade em questão para a realização do estudo, optamos por analisar os subprojetos de quatro cursos distintos de licenciatura ofertados em diferentes regiões do estado (um da região norte, um da região sul, um da região leste e um da região oeste do estado), tendo em vista conhecer diferentes áreas e contextos formativos. São eles: Licenciatura em Física, Licenciatura em LetrasPortuguês/Inglês ${ }^{6}$, Licenciatura em Matemática e Licenciatura em Química.

A seguir, apresentamos uma tabela com as principais características de cada subprojeto analisado e o número de participantes:

Tabela 1 - Dados gerais dos subprojetos analisados

\begin{tabular}{|c|c|c|c|c|c|}
\hline \multicolumn{6}{|c|}{ PIBID de uma universidade federal } \\
\hline \multicolumn{3}{|c|}{01 Coordenador institucional } & \multicolumn{3}{|c|}{$\begin{array}{c}02 \text { Coordenadores de área de gestão de processos } \\
\text { educacionais }\end{array}$} \\
\hline $\begin{array}{l}\text { Subprojetos } \\
\text { PIBID }\end{array}$ & $\begin{array}{l}\text { Início das } \\
\text { atividades }\end{array}$ & $\begin{array}{c}\mathrm{n}^{\mathbf{0}} \mathrm{de} \\
\text { coordenadores de } \\
\text { área }\end{array}$ & $\begin{array}{c}\mathbf{n}^{0} \text { de } \\
\text { supervisores }\end{array}$ & $\begin{array}{c}\mathrm{n}^{0} \mathrm{de} \\
\text { colaboradores }\end{array}$ & $\begin{array}{c}\mathrm{n}^{\mathbf{0}} \text { de } \\
\text { bolsistas de } \\
\text { iniciação à } \\
\text { docência }\end{array}$ \\
\hline Física & 2010 & 01 & 04 & 03 & 24 \\
\hline Letras-Inglês & 2011 & 01 & 01 & 0 & 10 \\
\hline Matemática & 2012 & 01 & 02 & 03 & 12 \\
\hline Química & 2012 & 01 & 03 & 01 & 10 \\
\hline
\end{tabular}

Ano de referência: 2013

Fonte: Elaborado pelas autoras

${ }^{6}$ Apesar de ser um único curso - Letras-Português/Inglês -, os subprojetos Letras-Português e Letras-Inglês são independentes. Neste estudo, apenas o subprojeto Letras-Inglês foi objeto de análise.

RIAEE - Revista Ibero-Americana de Estudos em Educação, Araraquara, v. 16, n. 4, p. 2509-2538, out./dez. 2021. e-ISSN: 1982-5587 
A análise e discussão dos dados apresentados neste artigo respaldaram-se em um referencial teórico (FRANÇA, 2006; GATTI; BARRETO, 2009; GARCÍA, 2010; ZEICHNER, 2010; TARDIF, 2012) e nas bases legais que regulamentam e dispõem sobre o PIBID, na política nacional de formação de professores e na interpretação que os sujeitos que participam deste Programa fazem sobre suas influências, contribuições, limitações e desafios na relação entre escola e universidade.

Para a discussão dos dados foram utilizados alguns excertos retirados das entrevistas realizadas com os participantes. Por razões éticas, a universidade e os quatro subprojetos do PIBID analisados neste estudo não foram identificados. Os subprojetos foram denominados de A, B, C e D, aleatoriamente, sem relação com a ordem em que foram apresentados na Tabela 1. Para diferenciar os relatos dos sujeitos que participaram do estudo foram também utilizadas algumas siglas: Coordenador de Área de Gestão de Processos Educacionais (CG), Coordenador de Área (CA), Supervisores (S), Colaboradores (C) e Bolsistas de Iniciação à Docência (B). Assim, ao final de cada relato é apresentada entre parênteses a sigla que corresponde ao subprojeto analisado seguida da sigla correspondente ao sujeito narrador.

\section{A relação entre as escolas e a universidade}

Diferentes estudos e pesquisas (NÓVOA, 2009; SHULMAN, 2005; GARCÍA, 2010; ZEICHNER, 2010; TARDIF, 2012) têm discutido sobre a importância e a necessidade de se estabelecer, no processo de formação docente, a integração entre os saberes acadêmicos, adquiridos na universidade, e os saberes da prática, adquiridos no contato com a profíssão. Alguns desses estudos defendem a ideia de uma verdadeira articulação entre a formação inicial e o campo da prática por meio da criação de um "terceiro espaço de formação", ideia discutida por Zeichner (2010). Nesse espaço, tanto a universidade quanto a escola atuariam na formação dos futuros professores por meio de atividades, ações e estratégias devidamente orientadas e fundamentadas que poderiam contribuir, ao longo de todo o processo, para superar ou minimizar a cisão entre a teoria e a prática da profissão, ainda tão presente em muitos cursos de formação inicial de professores.

Segundo Zeichner (2010), a ideia de um terceiro espaço advém da teoria do hibridismo, sendo esta a compreensão dos sujeitos sobre o mundo extraída de múltiplos discursos. Essa ideia vai ao encontro, também, do que defende Tardif (2012) sobre as múltiplas e diferentes fontes de saber. Segundo o autor, o saber docente é plural, compósito e heterogêneo porque envolve conhecimentos bastante diversos, provenientes de fontes variadas 
e de naturezas diferentes. Para este autor, tais conhecimentos estão na confluência de vários saberes, oriundos, por exemplo, da sociedade, das universidades (saberes disciplinares), da instituição escolar e dos outros atores educacionais (saberes experienciais), entre outros. Assim, partindo de tais princípios, faz-se imperativo considerar essas múltiplas fontes de saber no processo de formação docente, as quais, articuladas entre si, integram o conhecimento profissional.

Todavia, para que uma formação seja desenvolvida nessa perspectiva, é necessário, além de uma sólida compreensão dos conteúdos acadêmicos e disciplinares, que os futuros professores mantenham contato com o contexto profissional num momento considerado por Zeichner (2010) como de inserção à prática, sob a orientação cuidadosa de um professor regente de turma. Tal contato deve extrapolar, todavia, aquele realizado em situações de estágio supervisionado ou de práticas de ensino, nas quais, em muitos casos, a prática é frequentemente considerada o campo de aplicação da teoria adquirida na universidade. Além disso, a inserção deve proporcionar, para além do contato com o contexto da prática, sua compreensão a partir dos conhecimentos teórico-práticos adquiridos no curso de licenciatura, assim como esses devem ser utilizados como subsídio à problematização da prática e da experiência docente. Tal proposta, porém, supõe que a parceria entre universidade e escola seja realizada de uma maneira menos hierárquica, constituindo-se como uma nova oportunidade de aprendizagem para professores em formação.

A partir das entrevistas realizadas com os participantes, podemos observar que o PIBID tem, em certa medida, contribuído para a construção desse trabalho colaborativo entre as duas esferas. Quando questionados sobre a existência dessa relação, alguns deles relataram:

Eu acredito que uma das contribuições [do PIBID] é a desmistificação de que quem trabalha na universidade é mais importante que quem está trabalhando na educação básica por conta do trabalho em colaboração que os dois órgãos realizam na formação de futuros professores (DCA, 2013, grifos nossos).

Sim, eu acho que sim. Eu acho que ajuda pros dois lados, porque permite essa formação inicial dos nossos alunos, permite a formação continuada dos professores, porque quer queira quer não, elas [professoras supervisoras] estão em contato com novas coisas, novas formas de abordagem, novos textos, novos estudos, porque elas estão aqui. Então isso ajuda lá. E nos alunos mais ainda, porque aí os alunos não vão ficar presos a uma única aula, a um único tipo de ensino, eles vão poder ver outras coisas de formas diferentes. Então eu acho que é colaboração pra todo lado (DC, 2013, grifos nossos).

Eu acho que são os dois, eu acho. Porque como a gente ajuda, eu acho, como a universidade indo pra escola, a gente acaba ajudando os alunos $e$ 
proporcionando aulas diferenciadas acaba que eles também ajudam a gente, porque eu sei, se eu não tivesse no PIBID, acho que no estágio eu estaria frita, porque eu nunca tinha entrado numa sala de aula não sendo aluna e o PIBID, nesse ponto, me ajudou. No começo, eu morria de vergonha e era dificil, então acho que a gente ajuda os alunos e professores também, porque a gente acaba dando ideias pra eles, como os alunos também ajudam a gente. Então acho que talvez ali, tenha uma relação (AB, 2013, grifos nossos).

Ainda de acordo com alguns dos participantes, a parceria entre essas duas instituições tem também proporcionado a alguns dos alunos da educação básica o conhecimento e o contato com a Universidade, suas atividades e estrutura:

Já trouxemos ai algumas turmas para conhecer o laboratório aqui da [universidade] (AS, 2013).

$O$ professor [supervisor] vai trazer os alunos dele aqui amanhã para conhecer a universidade, os alunos que trabalham com os meninos do PIBID. Então amanhã a gente vai receber eles aqui de manhã, então eles vão ficar com a gente aqui amanhã junto com os alunos do PIBID. Então eu vejo que essa interação a gente conseguiu (BCA, 2013, grifos nossos).

Todavia, concordamos com França (2006) quando afirma que pensar na possibilidade de construção de parcerias entre universidade e escola implica, necessariamente, uma maior compreensão por parte dos profissionais de ambas as instituições acerca de seu papel como agentes formadores. No caso específico do PIBID, implica a valorização, o trabalho, o comprometimento e o envolvimento tanto da comunidade universitária quanto da comunidade escolar no trabalho realizado, tendo em vista o desenvolvimento de práticas tão compromissadas quanto aquelas que são cotidianamente realizadas por muitos docentes nas escolas. Com isso, seria possível almejar uma formação qualitativamente melhor de todos os envolvidos direta ou indiretamente no Programa. Tal trabalho, todavia, demanda uma maior abertura e contrapartida por parte de ambas as instituições no sentido de propiciar uma ação colaborativa que defina as bases para os objetivos propostos pelo Programa para a formação e atuação de seus envolvidos.

\section{O papel da universidade no processo de iniciação à docência}

De acordo com dados obtidos pelas entrevistas, a Universidade analisada tem oferecido, em algumas situações, contrapartida para o desenvolvimento das atividades do PIBID. Isso pode ser evidenciado na narrativa do coordenador institucional, segundo o qual a instituição disponibiliza, quando necessário, apoio logístico, de transporte e de custeio para 
algumas atividades do Programa. O mesmo pode ser observado nos relatos de um dos coordenadores de área entrevistados. Todavia, com base nos relatos dos demais participantes do estudo, falta apoio da universidade, especialmente no que diz respeito à disponibilização de espaço para reuniões e encontros entre os participantes, bem como para a discussão e planejamento das ações que serão realizadas. Quando questionados sobre a existência ou não de contrapartida da universidade para o PIBID, dois coordenadores de área relataram:

Não. Não tem. O apoio que nós tivemos do nosso departamento e principalmente da coordenação do curso, quando houve uma reestruturação física aqui, que a Química saiu e nós ganhamos mais espaço. Nossa demanda foi atendida pela coordenação do curso, que entendia perfeitamente e ajudou a gente e a chefia de departamento. Mas o [coordenador institucional] não tem isso da universidade. Isso ele vai poder te contar um pouquinho melhor. Ele não tem uma sala. A gente precisa ter uma sala pra gente poder trabalhar pelo PIBID, porque, afinal de contas, isso demanda... Ainda mais o coordenador institucional... Uma sala com computador, com impressora... É o mínimo que a gente pede. Mas infelizmente isso ele não conseguiu. Ele trabalha, você vê lá, conosco, na sala usando a estrutura da sala. Telefone... Ele precisa fazer ligações... Às vezes são ligações delicadas que ele tem que fazer e está lá no meio de quatro outros professores. Inclusive, uma coordenadora de PIBID, então ele não tem privacidade $e$ isso eu acho que a universidade... A gente entende toda a falta de estrutura que tem, mas a universidade eu acho que está abrindo muitos... Participando de muitos processos, muitos projetos, $e$ a demanda por espaço está ficando um pouquinho pra trás, um pouquinho a desejar (ACA, 2013, grifos nossos).

O apoio fica na promessa por enquanto porque eu pedi uma sala pro PIBID porque um projeto desse tem uma amplitude muito legal e a sala que eu utilizo hoje não é a sala do PIBID, é a sala do laboratório de ensino da [conteúdo específico D] que está quase sendo conhecida por todo mundo como a sala do PIBID porque eles usam o tempo todo. Então eu gostaria de uma sala na universidade. Nosso apoio é no sentido na inauguração de edital, essas coisas, mas justamente em razão disso é que talvez o PIBID seja bem autônomo, eu diria. A gente até comunica o que está fazendo, mas não fica pedindo o que se pode ou não fazer. Daí eu chego pro meu coordenador e falo, "olha, eu vou fazer uma oficina nas escolas". Eu chego pro diretor geral e falo, "olha, eu tenho 12 alunos pibidianos selecionados". Chego pro diretor de graduação e falo, "olha, eu quero um edital assim, assim e tal... está prontinho, é só você lançar". Então é nesse sentido que eu tenho o apoio deles (DCA, 2013, grifos nossos).

Em alguns casos, a ausência de visibilidade e de apoio da instituição ou de alguns de seus campi ao Programa, ou mesmo a forma como a universidade e seus docentes têm olhado, atuado e investido nos cursos de licenciatura, pode refletir em seu desconhecimento e desvalorização por parte dos que não participam do PIBID, como é possível observar nos relatos de alguns coordenadores e bolsistas de iniciação à docência entrevistados: 
Às vezes tem aquele "ah não, orientaçães de PIBID não vale, o que vale é orientação de TCC e tal, de estágio". Então, porque isso você não recebe pra fazer. Agora eles estão recebendo à parte, então, há uma sobrecarga... Eles precisam resolver essa questão, porque envolve aquilo ali, envolve uma bolsa. [...] por mais que eu diga, "oh tem tantos orientandos, tem isso, tem aquilo, aquilo outro", mas eu não tenho alívio nenhum, nunca tive alívio nas aulas nem nas orientações de outros. Porque eu sou professora, porque eu tenho a coordenação do PIBID (CCA, 2013, grifos nossos).

Aqui [o PIBID] ainda é meio desconhecido, viu? Sinceramente, eu já andei reclamando, mando e-mails, de vez em quando sai um edital ai da fundação, aí coloca lá no finalzinho que tem PIBID. Pode participar o pessoal da iniciação científica, da iniciação tecnológica, aí eu mando e-mail para e falo, "escuta, e o PIBID?". Ai ele fala, "uhn, esqueci", ai ele faz uma errata e corrige. Mas ai vem um outro edital e acontece a mesma coisa. [...] Então quer dizer, a própria universidade ainda não sabe se insere o PIBID em algumas atividades. Então isso eu percebo. [...] Tem professor que eu acho que nem conhece que tem o PIBID aqui no campus. [...] e eu percebo assim também, existe, existe um certo desprezo. Como se o aluno do PIBID fosse menos importante do que um aluno da iniciação científica. E isso eu já percebi aqui dentro também. Então às vezes em um bate-papo com um professor ou outro assim, você percebe que para ele é mais importante o aluno da iniciação científica do que ter 18 alunos do PIBID para o campus. Então... entra naquela questão social, de novo não valoriza a formação dos professores. Nem na própria universidade nós valorizamos (BCA, 2013, grifos nossos).

Alguns não valorizam. A maioria não. Eles enxergam assim, "olha, é dinheiro desperdiçado". Por quê? Porque pensa muito naquela pesquisa. É o pensamento quadradinho. Pensamento, assim, bom, é, "eu quero saber da minha pesquisa, como eu vou atingir os objetivos da minha pesquisa". Então, isso tem importância. Porque eles enxergam que artigo na área de educação é menos importante... (CG, 2014, grifos nossos).

Os estagiários têm que passar o dia inteiro aqui, o aluno vai pra casa só de noite, e ele tem direito ao café e a gente não tem, a gente não tem os direitos que o PIBIC tem, por que a gente não tem? Eles falam que é pelo fato da gente não trabalhar na escola, mas poxa, a gente passa a maior parte do tempo aqui, a gente tem que ir lá na sala, tem a reunião e a gente tem que vir pra cá planejar o conteúdo e fora que a gente planeja fora do horário, então, por que a gente não tem os mesmos direitos da iniciação científica, eu acho que é muito desvalorizado, pode ser pelo projeto ser novo, fato, ou pode ser por quê? Porque o nosso grupo é um curso de licenciatura... (AB, 2013, grifos nossos).

$\dot{E}$, eu acho que assim, na maioria dos cursos de licenciatura a gente é, entre aspas, esquecido. Os outros cursos, que aqui tem o curso de engenharia que tem muita tradição, então é muito voltado pro curso mesmo (AB, 2013, grifos nossos).

Dois alunos no curso que não são do PIBID, eles estavam brincando assim "ah, se eu achar que as matérias de [conteúdo especifico D] pura são muito dificeis, eu vou fazer meu TCC sobre educação". Falaram bem assim... ai eu fiquei pensando "nossa, mas até aqui os meus colegas desvalorizam a nossa profissão" porque de certa forma é uma forma de desvalorização, falando

RIAEE - Revista Ibero-Americana de Estudos em Educação, Araraquara, v. 16, n. 4, p. 2509-2538, out./dez. 2021. e-ISSN: 1982-5587 
assim que é mais fácil, a outra é mais difícil. É estranho pensar nisso (DB, 2013, grifos nossos).

Vou contar uma história que aconteceu no fim de ano, teve um [grupo do subprojeto] PIBID que foi no miniauditório, então, foram três dias, na $2^{a}, 3^{a}$ e $4^{a}$ antes do recesso, dai o público foi praticamente nós mesmos. Estava aberto a todos da universidade, e acho que todos os interessados também seriam de outros PIBIDs, mesmo assim, não compareceram. Não existe... Bom, uma coisa que o outro grupo comentou, também, que, às vezes, não existe contato dentro da própria instituição entre os PIBIDs (AB, 2013, grifos nossos).

A partir dos relatos apresentados, podemos observar que alguns participantes consideram que o PIBID não tem gozado do mesmo valor que outros projetos e programas desenvolvidos na universidade. Tal desvalorização, segundo os participantes, apresenta-se sob diferentes maneiras: entre os professores do mesmo departamento, entre professores de outros cursos, entre os próprios estudantes de licenciatura, entre estudantes de outros cursos e projetos e entre os diferentes subprojetos do mesmo campus.

Certamente, o fato de o PIBID ser ou não valorizado dentro da instituição depende, também - e em certa medida -, de sua abrangência na instituição (em termos de número de estudantes beneficiados, por exemplo), bem como da divulgação, visibilidade e da importância que os próprios membros dão às atividades nele desenvolvidas. Como podemos observar, existe uma preocupação de alguns dos subprojetos analisados em socializar tais atividades com a comunidade acadêmica por meio de seminários e encontros; todavia, mesmo com tal iniciativa, muitos parecem ainda não se preocupar em conhecer o PIBID e os trabalhos nele desenvolvidos. Um dos motivos apresentados pelos participantes se refere ao fato de o Programa estar vinculado a um curso de licenciatura.

De acordo com Gatti (2000) e Gatti e Barreto (2009), vários estudos acadêmicos mostram que no modelo universitário brasileiro as licenciaturas têm sido consideradas, historicamente, como uma formação de segunda categoria face aos demais cursos superiores. Com isso, a formação de professores passa a ser entendida como uma atividade de menor categoria, e quem a ela se dedica passa a ser pouco valorizado. Segundo as autoras, decorre daí uma ordem hierárquica na academia universitária: as atividades de pesquisa e de pósgraduação têm reconhecimento e ênfase, e a dedicação ao ensino e à formação de professores supõe perda de prestígio acadêmico. Todavia, como aponta Libâneo (2005), a desatenção das universidades em relação aos cursos de licenciatura, aliada a outros aspectos de mesma importância, pode dificultar ou até mesmo impedir a efetivação de políticas públicas de formação docente. 
Tendo isso em vista, é imperativo que a universidade, enquanto lócus privilegiado de formação docente, apoie e valorize os cursos de licenciatura, seus estudantes e os profissionais que nele atuam. Uma das formas de reconhecimento pode se dar pela valorização do PIBID por parte da instituição que, segundo o coordenador institucional e uma das coordenadoras de gestão entrevistadas, tem ocorrido de maneira satisfatória:

Tudo que a instituição pôde fazer pra nos ajudar com relação ao PIBID eles fizeram, em periodos, por exemplo, que nós não tínhamos verbas, precisávamos deslocar pros campus, eles bancavam as diárias, passagens e tudo mais, então eles sempre apoiaram, então esse foi o ponto mais importante, de apoio (CG, 2014, grifos nossos).

Outra coisa que eu vou te falar que é legal, além do dinheiro da Capes a gente tem um baita apoio da [universidade], entende? Já vi a [universidade] ceder diárias da [universidade] para alunos do PIBID porque o projeto não tinha mais, já vi a [universidade] pagar algumas custas, por exemplo, de eventos que foram organizados para o PIBID, certo, porque o PIBID não tinha rubrica para pagar isso, está entendendo? Eles pedem veículo, nossa, eles fazem tudo. Porque a [universidade] podia entender assim, "ah não, o PIBID tem o seu recurso, então nós não vamos dar nada”. Bem pelo contrário, nossa, a pró-reitoria da graduação abraçou o projeto assim, e tudo que a gente precisa mesmo e eles podem fazer, eles fazem. Mesmo sem burocracia também, interagindo e tal. [...] Então, poxa, como não trabalhar bem assim quando a própria universidade abraçou o projeto? Mas ela não faz isso só para o PIBID, não é o filhinho queridinho. Ela faz isso para todos. Faz para outras coisas e tal. Mas veja, nesse caso, nós somos tratados muito bem. [...] Claro, isso pode ser a nível de campus, também, pode ser também. Eu não conheço a realidade de todos os campi (CI, 2014, grifos nossos).

Como podemos observar nos relatos, a Universidade tem, ao menos no campus sede, atuado como ponto de apoio ao PIBID em suas necessidades, especialmente naquelas relacionadas a recursos financeiros. Todavia, tendo em conta a amplitude do projeto e a natureza multicampi da instituição, faz-se necessário que não apenas um campus, mas todos os campi, no papel de suas diretorias, apoiem e valorizem o Programa em suas dimensões e necessidades.

Considerando a universidade como um dos polos que integram o Programa, é importante que esta incentive e se envolva com o projeto, oferecendo-lhes as condições estruturais e o apoio pedagógico que se fizerem necessários para o seu desenvolvimento. E, tendo em vista a natureza multicampi da instituição em questão, isso se faz necessário não apenas em um de seus campi, mas em todos eles, de maneira integrada. Da mesma forma, fazse indispensável uma maior valorização, por parte de seus profissionais, do trabalho desenvolvido tanto pelos professores quanto pelos estudantes dos cursos de licenciatura, bem 
como uma melhor compreensão do Programa enquanto Projeto de Formação da Instituição. Tal compreensão contribuirá não apenas para a valorização do PIBID na Universidade mas, igualmente, para a valorização dos cursos de licenciatura e da própria formação docente.

De acordo com relatos de uma das coordenadoras de gestão entrevistadas, a instituição tem valorizado o trabalho desenvolvido pelos professores que estão envolvidos em projetos, dentre eles o PIBID, no momento de sua progressão na carreira. Segundo esta professora, isso demostra, de alguma maneira, certa apreciação e incentivo por parte da instituição ao trabalho realizado por esses profissionais. Todavia, segundo ela, para que haja uma maior valorização dos coordenadores de área e colaboradores do PIBID, é preciso que a instituição e os próprios participantes do Programa o considerem também como um campo de pesquisa, neste caso particular, como um campo de pesquisa educacional, a fim de que os resultados e a produção dele decorrentes sejam valorizados, também, como pesquisa docente.

Em sua narrativa, a coordenadora de área do subprojeto A reforçou, também, a necessidade de um maior apoio por parte da universidade ao trabalho desenvolvido pelos coordenadores de área:

Porque, veja, muitos não se envolvem porque a universidade não apoia... Você não tem... A partir do momento que você está na escola aquilo não é computado como tua carga horária, carga didática... Então muitos professores [coordenadores de área] pensam da seguinte maneira... E eu não tiro a razão deles... "Ah, não vai computar como minha carga didática... Então eu vou lá na escola, vou ficar 10 horas por semana na escola, mas a universidade vai me cobrar essas 10 horas de permanência... Isso não é justo"... Então ele acaba não indo porque ele não vai ter computado isso na sua carga didática e ele vai ter que fazer a mais na universidade (ACA, grifos nossos).

Segundo essa coordenadora, o mesmo ocorre aos professores que orientam as disciplinas de estágio supervisionado, aos quais é atribuída a orientação de muitos alunos e a supervisão de suas atividades nas escolas, sem que, em alguns casos, as horas destinadas a esse trabalho nas escolas sejam computadas em sua carga horária de trabalho na universidade. A carga de trabalho e a responsabilidade inerente a essas atividades - PIBID e estágio supervisionado -, aliada à desvalorização por parte de alguns colegas de trabalho, acaba por desmotivar ou até mesmo afastar muitos professores desses encargos. 


\section{O papel das escolas e das redes de ensino no processo de iniciação à docência}

Realidade semelhante vivenciam os professores da educação básica. Mancebo, Maues e Chaves (2006), ao discutirem sobre as implicações da crise da reforma do Estado e da universidade para o trabalho docente, argumentam que este trabalho tem sido marcado na atualidade pela precarização e intensificação, sendo uma das possíveis explicações para isso o descompasso entre as políticas públicas, os programas de formação, a organização do trabalho docente e a prática e motivação dos professores. Muitas vezes, políticas e programas são elaborados de modo a aumentar as atividades docentes sem, contudo, alterar significativamente suas condições objetivas de trabalho. Desta forma exige-se mais do professor nas mesmas condições. Essa realidade é também discutida por Lessard (2010), segundo o qual há muito de utópico no modelo de formação docente, especialmente de formação continuada, uma vez que ele supõe que a melhoria da escola recai essencialmente sobre os professores. Daí resulta a ambivalência dos docentes em relação às políticas de formação: eles desconfiam da autonomia que lhes é concedida por ela ser "outorgada" pelas instâncias superiores; veem aumentada a sua carga de trabalho e ampliadas suas responsabilidades e, em contrapartida, não sentem o devido respaldo dos respectivos sistemas de ensino.

De acordo com dados das entrevistas realizadas com os coordenadores de área, a participação dos professores da educação básica nos momentos de discussão e planejamento das atividades e ações do PIBID constitui-se elemento essencial para a formação dos envolvidos. Assim, para que esses momentos de formação ocorram, em alguns casos o cronograma de reuniões é adequado em função dos horários disponíveis pelos professores supervisores. Todavia, mesmo diante de adequações, alguns professores supervisores não conseguem participar das reuniões realizadas ou participam com pouca frequência. Segundo dados das entrevistas, a maioria dos professores supervisores trabalha 40 horas semanais e em mais de uma escola, o que dificulta sua integração nas atividades realizadas na universidade e, em algumas situações, sua atuação nos momentos de planejamento das intervenções. Há que se considerar ainda o fato de que, como apontam Gatti e Barreto (2009), o número de horas semanais efetivamente trabalhadas pelos docentes costuma ultrapassar o número de horasaula informadas, sendo o primeiro maior, englobando também o tempo empregado na preparação das aulas, correções de avaliações e nos estudos realizados fora do horário escolar, o qual deveria ser acrescido ao tempo de ensino para melhor dimensionar a jornada semanal de trabalho dos docentes. Por esses e outros motivos, muitos professores da educação básica 
vinculados ao PIBID não encontram tempo para participar das atividades do Programa também na Universidade e, com isso, sua participação e supervisão acabam se limitando, em muitas situações, a seus próprios locais de trabalho - em sala de aula ou nos poucos momentos de planejamento na escola.

A coordenadora de área do subprojeto A optou pela realização de reuniões quinzenais, considerando essas dificuldades e visando ampliar a participação dos professores supervisores - e dos demais participantes - nas atividades e nas reuniões, com vistas a contribuir para um melhor desempenho dos alunos bolsistas:

Nessa reunião individual que dura uma hora e meia, mais ou menos, nós discutimos as estratégias. Eu convido os professores supervisores também pra estarem participando quando eles podem. Às vezes a gente marca no meio da tarde para o supervisor poder estar aqui. Dai a gente... Todo o planejamento das atividades, calendário, cronograma, desenvolvimento do projeto, leituras, tudo isso é acertado nessas reuniões. Eu dou trabalho pra eles. Ai eles me mandam pra eu ter tempo de ler pra próxima reunião. Por isso que é quinzenal. Ai eu dou trabalho eles me mandam, por exemplo, uma revisão bibliográfica, eles mandam pra mim, eu leio, dou o retorno na próxima reunião. Então por isso que a gente dá esse espaço... Porque a gente fazia reuniões semanais, mas viu que não estava sendo produtivo. Não dava tempo de eles mandarem, fazerem, pra que eu desse um retorno. Então a gente resolveu fazer quinzenal (ACA, 2013).

Segundo a coordenadora, o contato constante com as escolas parceiras do subprojeto e sua participação em algumas das aulas ministradas pelos professores supervisores são essenciais para estabelecer a confiança do trabalho desenvolvido e incentivar esses professores a também participarem das atividades realizadas na universidade: "Eu tento muito trazer os supervisores pra universidade e pra isso eu vou à escola. Porque quando eles começam a ver que eu estou lá na escola eles falam: 'Opa, eu também vou lá na universidade' [...]" (ACA, 2013, grifos nossos).

Certamente, o contato e a participação direta do coordenador de área do PIBID com as escolas contribuem não apenas para estreitar a relação entre a universidade e a escola, mas, igualmente, para fortalecer e valorizar a parceria de trabalho e de formação com os professores supervisores da educação básica que se dispuseram a participar desse Programa. Em todo e qualquer processo de formação, não basta que a escola e seus profissionais adentrem a universidade; é necessário também que a universidade, enquanto lócus de formação, se aproxime da escola, considerando-a igualmente como espaço de formação e como ponto de partida para a problematização e análise dos problemas educacionais e das necessidades de formação e atuação docente. 
Candau (1996), ao discutir sobre a formação continuada de professores, defende que todo processo formativo deve ter como referência, entre outros aspectos, a prática, o reconhecimento e a valorização dos professores da educação básica. Para a autora, as necessidades docentes têm sua origem na prática e, por esse motivo, faz-se necessário partir dela para se compreender as necessidades que dela são emanadas. Essa mesma ideia é também defendida por Tardif (2012, p. 23), segundo o qual "o conhecimento do trabalho dos professores e o fato de levar em consideração os seus saberes cotidianos permite renovar nossa concepção não só a respeito da formação, mas também de suas identidades, contribuições e papéis profissionais". Afinal, a formação do professor se efetiva a partir do momento que conhecemos a realidade docente.

Partindo desses princípios, não nos parece gratuito que os programas de formação, como é o caso do PIBID, desconsiderem a realidade prática docente e as experiências e necessidades dos professores. Concordamos com Ferreira (2006) e García (2010) quando argumentam que propostas curriculares construídas sem considerar as opiniões e experiências do professor em exercício tendem a fracassar. Nelas, o professor sente-se como um mero realizador de propostas desenvolvidas por outras pessoas, o que sugere, em certa medida, um desprestígio da profissão do professor. Considerando tais aspectos, para que o PIBID possa contribuir também para a formação desses professores, é necessário que todos os envolvidos no Programa, e não apenas os alunos bolsistas, comprometam-se e se preocupem em também compreender e conhecer sua realidade de trabalho. Somente assim as ações e intervenções propostas e planejadas para serem desenvolvidas em sala de aula poderão ter efeito na atuação e na formação dos professores e futuros professores, como objetiva o Programa.

Da mesma forma, tendo em vista a proposta do PIBID de transformar os professores da educação básica em coformadores dos licenciandos e torná-los protagonistas nos processos de formação inicial para o magistério, seria necessário que as redes municipais e estaduais de ensino na qual eles se encontram vinculados disponibilizassem as condições necessárias, como, por exemplo, tempo e também espaço para que esses profissionais pudessem atender aos objetivos do Programa e atuar efetivamente na formação desses alunos, futuros professores. Esse é um dos aspectos também discutidos por uma das coordenadoras de gestão entrevistadas:

[...] Aí, fala assim, "Vamos participar de um evento. Dá pra trazer dinheiro, a gente paga a inscrição", "Não dá, não posso ir". Então, a participação deles [supervisores] é muito limitada. Muito, muito mesmo. Eles dão abertura pra os alunos trabalharem nas escolas. As escolas que a gente tem conseguido fazer parceria, elas têm dado uma abertura bem legal, os alunos

RIAEE - Revista Ibero-Americana de Estudos em Educação, Araraquara, v. 16, n. 4, p. 2509-2538, out./dez. 2021. e-ISSN: 1982-5587 
não têm dificuldade de trabalhar. Os professores se dedicam no tempo que eles estão lá, mas é só. Então, não existe essa devolutiva. A gente queria, por exemplo, os alunos, aqui, eles têm encontro semanais com os coordenadores de área, pra leitura de artigo, leitura de livros. Então, eles fazem apresentações. Então, a gente queria o supervisor nesse momento também, mas a gente não consegue. Já foi feito várias tentativas, não tem, a gente não consegue. E a gestão, ela, não pode interferir muito nesse quesito, por que o que acontece? É meio que a gente passar por cima da autoridade do coordenador de área. [...] Então, eu não procuro interferir. Mas eu entendo parcialmente um pouco essa tentativa de não comprometimento, porque elas têm uma carga horária muito alta, e, aí, vem toda aquela problemática. Pra viajar, tem que ir, às vezes, muitas vezes, pra longe, quem é que substitui esse povo nesse tempo que fica? Então, a gente tem a nossa realidade agora, que a gente dá 10 aulas por semana, 12 aulas por semana. Quero ver trocar com elas 40 aulas por semana. Não é? (CG, 2014, grifos nossos).

Segundo um grupo de participantes do II Fórum de Área do PIBID de 2013, para que haja uma maior integração entre as universidades e a Secretaria de Educação do Estado, é necessário que se incentive, autorize e oficialize a liberação dos professores supervisores para o desenvolvimento das atividades relacionadas ao PIBID. Essas atividades são as reuniões de discussão, orientação e planejamento (na universidade e na escola), a participação em eventos, tendo em vista socializar, junto aos demais participantes, os trabalhos realizados por meio do Programa.

Para além da disponibilização de tempo, se considerarmos o PIBID como um programa que, ao intervir na prática profissional docente, também influencia na formação dos professores da educação básica, seria necessário que tais redes de ensino incorporassem o tempo que eles utilizam para a atuação no Programa - ou ao menos uma fração desse tempo como parte de sua carga horária de trabalho e que também o considerasse como momento de formação continuada para fins de qualificação e progressão na carreira profissional. Afinal, não parece fazer sentido delegar responsabilidades ao professor sem oferecer-lhe, em contrapartida, as condições necessárias para o cumprimento de suas funções e a devida valorização do trabalho por ele desenvolvido.

É importante ressaltar que o fato de os professores supervisores serem remunerados configura-se, sem dúvida, como um avanço no que se refere à valorização das funções desempenhadas por esse profissional no processo de formação de futuros professores. Todavia, além de valorização financeira, esses profissionais necessitam, igualmente, ter reconhecidas suas funções em termos de carreira profissional, bem como condições apropriadas de trabalho para que essas funções sejam desempenhadas de modo a colaborar efetivamente na formação docente proposta e na qualidade dessa formação. E para que essas 
condições sejam alcançadas, faz-se necessária uma articulação orgânica entre o que propõem as políticas públicas para os processos de formação e atuação docente e as demandas e necessidades da realidade em que tais processos se desenvolvem.

Outrossim, considerando os objetivos do PIBID para a formação de estudantes e professores, faz-se também necessário que as escolas e as redes nas quais elas se encontram vinculadas se envolvam com o Projeto. Segundo as coordenadoras de gestão entrevistadas, faz-se necessária uma maior articulação entre as secretarias e núcleos regionais de ensino com a universidade, tendo em vista uma melhor divulgação do PIBID, seu apoio, incentivo, valorização, bem como o conhecimento dos cursos e programas de formação que são desenvolvidos por intermédio do Programa e pela universidade:

Eu acho que a rede de ensino deveria estar mais atrelada à universidade, até pra fazer divulgação para as escolas. Porque, hoje, é muito, não sei nem se a gente pode dizer particularizado, mas o que acontece? O PIBID, ele não é divulgado em todas as escolas. Em geral, o Núcleo de Educação, o Núcleo, às vezes, ele recebe a informação do PIBID, e, aí, às vezes, ele destina para algumas escolas. Mas nem todas as escolas têm conhecimento do programa. Entendeu? Eu sei que o Núcleo tem se esforçado para receber as informações que o PIBID passa, e fazer essa ampla divulgação. Mas, muitas vezes, a divulgação para na mesa do diretor, também, que não repassa para os professores. Porque a gente sabe que, muitas vezes, eles pensam, "bom, é mais uma carga de trabalho". Então, fica ali. Então, eu acho que falta não é só a escola ir à universidade. Os núcleos também teriam que fazer um tripé com o PIBID, pra, de repente, funcionar melhor. Até pra divulgar cursos que PIBID oferece pra todas as escolas. Porque, não obrigatoriamente só o professor supervisor, por que aquele professor que não é supervisor não pode participar de um curso? (CG, 2014, grifos nossos).

O estabelecimento de uma ação conjunta entre as IES e a Secretaria de Educação do Estado para o estreitamento da relação entre universidade e escola também foi um dos aspectos apresentados no relatório de um dos grupos de discussão do já citado II Fórum de Áreas do PIBID (2013). Nele, os participantes do Fórum ressaltaram a importância de a SEED do Estado conhecer melhor os objetivos do PIBID, participar com maior frequência de suas atividades, dando-lhes o apoio necessário, bem como analisar seus impactos nas escolas e em seus professores. Ao oferecer as condições materiais necessárias, os representantes dos Núcleos Regionais de Ensino podem estabelecer a devida parceria e contato com as escolas e as universidades que compõem cada projeto. Por outro lado, os professores e técnicos presentes advertiram sobre a necessidade de um maior compromisso das universidades em manter a Secretaria informada sobre os Projetos PIBID desenvolvidos nas escolas e sobre os sujeitos nele envolvidos. Além desses aspectos, os participantes do Fórum argumentaram 
também sobre a necessidade de um trabalho colaborativo entre universidade e escola, tendo em vista a superação da verticalidade e hierarquização que historicamente tem permeado a relação entre essas duas instituições.

Esse é também um dos aspectos amplamente discutidos pela literatura acadêmica sobre formação docente. Como exemplo, podemos citar o estudo realizado por Reali e Tancredi (2005), no qual, analisando os processos de aproximação entre universidade, escola e família a partir de pesquisas desenvolvidas em escolas públicas, revelaram a presença de interações superficiais construídas entre essas instâncias. Segundo as autoras, na maioria dos casos as relações entre universidade e escola ocorrem de maneira vertical, predominantemente das universidades em direção às escolas, num falso diálogo durante o qual cada instância procura divulgar e reforçar sua própria perspectiva desconsiderando a do outro. Para essas autoras, a superação dessa verticalidade, porém, viria com o desenvolvimento de trabalhos colaborativos, nos quais as parcerias seriam construídas de forma mais igualitária, com respeito e apoio às ideias e perspectivas de cada instância formativa.

A mesma ideia é defendida no trabalho de Tauchen e Devechi (2016), em que o estreitamento das relações entre universidade e escola contribui para que ambas sejam vistas e valorizadas como participantes do processo de aprendizagem da docência, onde "uma colabora com a outra na renovação dos saberes". Além desses estudos, trabalhos como os realizados por Felício (2014), Gatti et al. (2014) e Oliveira, Rezende e Carneiro (2021), que analisam especificamente o PIBID, têm demonstrado a atuação deste Programa na criação de um fluxo de mão dupla entre academia e o contexto escolar, contribuindo para o fortalecimento da colaboração entre essas duas esferas e trazendo melhorias tanto para a formação inicial dos licenciandos quanto para a formação continuada dos docentes envolvidos. Corroborando com esses trabalhos e avançando nesse debate, os participantes entrevistados neste estudo entendem que, para que o PIBID seja desenvolvido numa perspectiva colaborativa, é necessária não apenas a mudança de atitude e de atuação da universidade perante a formação docente, mas, igualmente, um maior comprometimento e envolvimento das escolas parceiras no desenvolvimento do Projeto.

De acordo com dados obtidos pelas entrevistas, o fato de algumas escolas não compreenderem de forma clara os objetivos do PIBID tem dificultado a inserção de alguns bolsistas e o alcance de alguns dos objetivos propostos pelo Programa. Relatos de vários participantes, especialmente de um dos subprojetos, demonstram que, de modo geral, as escolas menores e localizadas em bairros periféricos das cidades são mais receptivas e abertas ao Programa e à Universidade do que as escolas centrais - ou, em alguns casos, escolas- 
padrão -, as quais, devido sua tradição e forma de organização, muitas vezes não se envolvem com o Programa e seus participantes de maneira satisfatória. Isso reflete também na atitude de alguns professores supervisores, como é possível observar nos relatos que se seguem:

O professor parecia que não tinha tempo para nós, porque primeiro que nós entramos no meio do ano lá no [escola de centro], isso foi ano passado e estava planejado na cabeça o que ele iria fazer, e o nosso grupo era uma coisa que estava atrapalhando o planejamento dele, então, era relutante, por exemplo, conceder um dia para a nossa intervenção (AB, 2013, grifos nossos).

Eu acho que deve variar bastante conforme o professor e, no caso, da escola em si. [...] Tem escola que acha "ah, estão ai para tapar buraco", não parece que faz questão da gente estar lá, entendeu? (AB, 2013, grifos nossos).

Varia do professor e da pedagoga também dentro do colégio. Tem pedagoga de um periodo, por exemplo, da manhã que gosta do PIBID e a da noite já não gosta, a gente vê tudo isso. Então, a gente vai no periodo que dá para conversar com aquela pedagoga (AB, 2013, grifos nossos).

Dependendo do tamanho do colégio você não percebe isso. A impressão que eu tenho é que quanto menor o colégio, mais problemas que o colégio tem, mais a participação do PIBID fica evidente, que daí envolve diretor, envolve professor... Agora, se você pega um colégio grande que nem, por exemplo, o [escola de centro], chegam os bolsistas lá e a direção não faz nem ideia dele, de quem está indo, por que está indo e para onde está indo, $e$ às vezes, nem a pedagoga está sabendo (AB, 2013, grifos nossos).

Eu acho que, assim como a universidade tem que ter essa receptividade, a escola, a direção tem que dar essa abertura pro professor trabalhar coisas novas em sala de aula. E essas duas [escolas de bairro] dão essa abertura. Já o [escola de centro] não porque é mais engessado, ele é mais padrão, [...] já está em outro patamar. As escolas que são mais carentes elas são mais fáceis de trabalhar. Por um lado, porque elas são mais carentes, elas facilitam mais o nosso trabalho. Mas por outro lado são mais dificeis pra nós porque é um desafio muito grande de nós atendermos às expectativas deles. [...] E eventualmente, quando é a semana de planejamento, [...] essas escolas que eu te falei da periferia, elas têm uma receptividade maior, então eles até pedem que os alunos bolsistas participem, é diferente (ACA, 2013, grifos nossos).

De acordo com os participantes, há nessa escola de centro subprojetos do PIBID de diferentes áreas do conhecimento. No entanto, mesmo com uma quantidade considerável de bolsistas, cursos e universidades articulados à instituição, esta não parece se envolver com o Programa e com sua proposta de formação. Segundo relatos dos bolsistas de iniciação à docência vinculados a essa escola, nela eles não são conhecidos por todos os funcionários (entre professores, técnicos e gestores) e são muitas vezes considerados apenas estagiários. 
De fato, em nada contribui um programa de iniciação à docência em uma escola na qual gestores, coordenadores e professores não se apresentam solícitos e envolvidos com seus objetivos. O PIBID não se configura apenas como um programa de formação aos alunos da licenciatura, mas, igualmente, aos professores da educação básica e da universidade que dele participam e, por esse motivo, contribui (ou deveria contribuir) também à universidade e à escola na qual estes se encontram vinculados. Considerando tal aspecto, é necessário que a escola como um todo - e não apenas o professor supervisor -, participe do Projeto e se preocupe, ao mesmo tempo, em compreendê-lo e em contribuir para o desenvolvimento de suas atividades.

Todavia, para que a escola compreenda e contribua com o desenvolvimento do PIBID, é preciso, antes de tudo, conhecê-lo. E no que se refere a esse aspecto, o professor supervisor tem um papel fundamental. Conforme disposto nas Portarias $n^{\circ}$ 260/2010 e n $n^{\circ}$ 96/2013 , é dever do professor supervisor informar à comunidade escolar sobre as atividades do projeto e compartilhar com a direção da escola e com seus pares as boas práticas do PIBID. Segundo relatos de um grupo de alunos bolsistas do subprojeto B, a escola na qual se encontram vinculados conhecem o PIBID e valorizam as atividades desenvolvidas: "No nosso colégio a gente é superpopular. Somos conhecidos, bem acolhidos. Tem outros PIBIDs: Geografia, Filosofia, Artes. A diretora conhece a gente, a pedagoga...” (BB, 2013).

De acordo com esse grupo de alunos, o PIBID passou a ser conhecido por todos da escola - e não apenas pelo professor supervisor e equipe gestora - quando organizaram, com o professor supervisor e o professor coordenador, algumas atividades voltadas a toda a comunidade escolar no período da Semana Cultural realizada pela escola. Além disso, de acordo com relatos dos bolsistas e do coordenador de área deste subprojeto, esta escola se mostrou, desde o início, comprometida com o Programa e com sua proposta de formação. O mesmo pode ser observado na narrativa de outro coordenador de área, segundo o qual uma das escolas parceiras não apenas conhece o PIBID, mas também se preocupa, oferece contrapartida e informa aos demais sobre o desenvolvimento das atividades realizadas pelo Programa:

Lá eu sei que todo mundo conhece. O diretor me manda e-mail às vezes perguntando como estão as coisas, se precisa de alguma coisa. Eu até estranhei o primeiro e-mail que ele mandou. Depois ele mandou mais uns

\footnotetext{
${ }^{7}$ Considerando o fato de que todos os projetos e subprojetos em vigor até julho de 2013 tiveram seus prazos de execução prorrogados até dezembro de 2013 e que nossos dados foram coletados no segundo semestre deste mesmo ano, tomamos como base de análise para este estudo a Portaria Normativa $n^{\circ}$ 260/2010 (em vigor até 17/07/2013) e a Portaria Normativa no 96/2013 (em vigor a partir de 18/07/2013).
} 
três, já estou acostumando agora. E aí, que é tão dificil de acontecer, não é? Ai tem o Facebook do colégio, e no Facebook do colégio, eles postam foto das oficinas do PIBID, escreve que é do PIBID, então eu percebo que todo mundo sabe que é uma coisa boa... a supervisora tem ido acompanhar as oficinas do sábado também pra os alunos não ficarem desamparados. [...] Então eu sei que nesse colégio está acontecendo esse abraço, esse reconhecimento e esse conhecimento (DCA, 2013, grifos nossos).

A presença e importância do PIBID dentro da escola também são relatadas por um dos professores supervisores entrevistados:

Então, no colégio que eu estou existem vários professores que estão participando de grupos de PIBID. Aqui da, no [universidade] sou eu apenas. Mas eu tenho um professor de Química, tem outro professor de [conteúdo específico A] lá também, professor de português e tal, que estão envolvidos na UFPR com os grupos de lá, entende? Então são vários professores que tem esse, todos os professores eles acabam trazendo esse trabalho do PIBID para dentro da escola e a escola está bem ciente, tem noção do que está acontecendo. E as atividades do PIBID elas acabam, assim, aparecendo dentro da escola também. Não é uma coisa isolada. Igual por exemplo, quando tem uma, algum evento da escola, uma semana cultural, alguma coisa assim, o PIBID está ali. Às vezes os projetos de intervenção, eles são vistos pelos professores também. Então eu acho que é uma característica de você também divulgar o trabalho, mostrar o que está sendo feito, até na própria convivência ali com os professores. Eles percebem e tal, a gente conversa também muito, eles perguntam como é que está o andamento e coisa e tal. $\boldsymbol{E}$ a gente consegue relatar o que está acontecendo dentro do projeto com os alunos, que estão envolvidos, as turmas que estão envolvidas. Então, eu penso assim, que o PIBID, os programas, os grupos do PIBID, eles desenvolvem os trabalhos ali, esse trabalho não passa despercebido, entende? (AS, 2013, grifos nossos).

Como podemos observar, o conhecimento e a compreensão do PIBID pela comunidade escolar dependem, ao mesmo tempo, do envolvimento de seus agentes (professores, gestores, alunos e demais funcionários) e do alcance e socialização das atividades realizadas pelos participantes do Programa dentro da escola. Naturalmente, as ações realizadas causam - ou deveriam causar - maior impacto junto ao professor responsável por supervisionar e orientar os bolsistas em sua inserção na escola; todavia, tais ações podem também ser estendidas - como propõe a Portaria que regulamenta o Programa - aos demais professores, seja da mesma área, seja de outras áreas do conhecimento. Para que isso ocorra, porém, é necessário, de um lado, interesse desses professores e incentivo da escola e, de outro, o comprometimento do professor supervisor e dos demais participantes do PIBID em informar e socializar a toda a comunidade escolar, nos momentos de planejamento, reuniões e atividades conjuntas, as ações realizadas pelo Programa na instituição.

RIAEE - Revista Ibero-Americana de Estudos em Educação, Araraquara, v. 16, n. 4, p. 2509-2538, out./dez. 2021. e-ISSN: 1982-5587 
Segundo relatos apresentados por alguns participantes, essa socialização não tem ocorrido em todas as escolas parceiras dos subprojetos analisados. A partir das narrativas dos participantes, é possível observar que, em alguns casos, apenas o professor supervisor que os acompanha conhece o PIBID, sendo os demais professores da escola, inclusive da mesma área do conhecimento, alheios às suas atividades: "O professor, pelo menos o de onde eu estou no colégio, ele entende o que é o PIBID. Mas o colégio, os outros professores, já não entendem. A diretoria, a supervisão também já pensam que é mais um estágio do que Iniciação à Docência" (AB). O mesmo é possível de ser observado nas narrativas de alunos bolsistas de outros subprojetos:

Eu acho que as atividades que a gente faz não são aproveitadas pelos outros professores, não que a gente saiba, porque se fosse passado elas iam falar "olha que legal, eu estou usando a atividade de vocês". Então eu acho que ninguém usou até agora (DB, 2013, grifos nossos).

Uma coisa que eu tenho uma reclamação da escola é que os diretores não conhecem nós. $O$ diretor não nos conhece, o coordenador não nos conhece, coordenadora... (BB, 2013, grifos nossos).

Além disso, segundo relato de uma professora supervisora, em alguns momentos é possível identificar certa resistência dos professores da escola e, de modo particular, dos professores da mesma área do conhecimento em trocar ideias e experiências sobre as atividades realizadas em sala de aula. Segundo essa professora supervisora, a profissão docente é marcada pelo individualismo e isolamento, o que dificulta e até mesmo prejudica o trabalho colaborativo e a socialização das ações que são desenvolvidas, por exemplo, pelo PIBID dentro da instituição. Por isso a necessidade de ações articuladas entre o ensino superior e a educação básica para que esse trabalho de divulgação, colaboração e socialização das atividades ocorra entre todos os professores, e não apenas entre os bolsistas do Programa.

De acordo com dois dos professores supervisores entrevistados, o fato de existir mais de um subprojeto do PIBID de áreas distintas do conhecimento em algumas escolas poderia facilitar o trabalho interdisciplinar entre os professores, o que, na prática, não acontece:

A [conteúdo especifico C] pode estudar Química, História, Geografia, toda e qualquer matéria. É possível criar essa interdisciplinaridade. Gosto muito, já fiz com Educação Física. Estou fazendo agora com formação de professores, com teatro, contos, que é o gênero. Eu vou buscando assim com os outros professores, mas os outros não aceitam muito, é difícil... É crenças, cada professor trabalha de seu modo, [...] há muito... bastante individualismo. Cada um tem uma característica de ensino, uma crença também, perfil, no ensino médio... difícil te dizer isso (CS, 2013, grifos nossos). 
Não existe integração entre grupos [diferentes subprojetos PIBID], infelizmente, isso aí não existe... acho que porque são grupos diferentes, de instituições diferentes, não sei... (AS, 2013, grifos nossos).

Desta forma, a articulação entre docentes de diferentes áreas e o desenvolvimento de atividades integradas nas escolas parceiras para a promoção da formação interdisciplinar, propostos pelas Portarias no 260/2010 e no 96/2013, deixam de ser contemplados. Como já discutimos, tal como a socialização dos trabalhos com a comunidade escolar, a integração das atividades e a formação interdisciplinar dentro das escolas não depende exclusivamente da ação da universidade - no papel dos coordenadores, colaboradores e bolsistas de iniciação à docência -, tampouco unicamente da escola - no papel dos professores supervisores e demais profissionais -, mas de ações articuladas e intencionais entre ambas as esferas, voltadas aos objetivos comuns de formação propostos pelo PIBID. Entretanto, como aponta Tancredi (2013), além de ações coletivas, o trabalho interdisciplinar depende, igualmente, de tempo para que os profissionais envolvidos desenvolvam uma postura holística no que se refere à produção do conhecimento. E, considerando as dificuldades de se desenvolver tal postura devido ao próprio formato de currículo disciplinar presente nas escolas, o PIBID pode constituir-se como um importante instrumento de construção de uma atuação global entre os professores e também entre eles e os bolsistas de iniciação à docência e professores universitários, tendo em vista a superação da fragmentação do conhecimento presente tanto nas escolas quanto nas próprias instituições de ensino superior.

\section{Considerações finais}

Num momento em que a Educação e muitos dos programas e ações de formação que dela fazem parte têm sido ameaçados, fazem-se imperativos estudos que contribuam para a análise de suas contribuições, limitações e desafios no sentido de fortalecê-los. A partir dos resultados obtidos nesse estudo, podemos observar que o PIBID tem favorecido a aproximação entre escola e universidade e contribuído para a desmistificação da concepção de superioridade de uma sobre a outra. Com isso, o dualismo entre conhecimento acadêmico e saberes profissionais e entre teoria e prática passa a ser gradualmente superado, favorecendo, em grande medida, a formação inicial dos estudantes da licenciatura, a formação continuada dos professores da escola e da universidade e o trabalho colaborativo entre os envolvidos no processo de iniciação à docência. 
Além disso, os dados nos permitiram observar que o PIBID tem possibilitado aos professores e estudantes das escolas de educação básica a aproximação com o ambiente universitário e, de maneira semelhante, favorecido um maior contato da universidade, seus profissionais e licenciandos com o contexto escolar, o que contribui ainda mais para o estreitamento e enriquecimento da relação entre as duas instituições educativas. Neste processo, tanto a universidade quanto a escola passam a se configurar como espaços de formação docente, cada uma com características, objetivos e especificidades diferenciadas.

No entanto, apesar de os relatos dos estudantes mostrarem a importância que o PIBID tem desempenhado na articulação entre o campo de formação e o (futuro) campo de atuação profissional, alguns dados nos permitem reflexões. Ao demonstrarem em suas narrativas o potencial do PIBID como preparação para a realização do estágio curricular ou mesmo insegurança em realizar esse estágio e ingressar na escola caso não tivessem participado do PIBID, alguns estudantes indicam a possibilidade de o curso de licenciatura não estar proporcionando a necessária e contínua articulação entre teoria e prática ao longo de todo o processo formativo. Segundo Felício (2014, p. 421), essa desarticulação, ainda que falaciosa, tem contribuído historicamente para o desenvolvimento de um processo de formação dicotomizado, "por meio do qual as polaridades não se complementam, uma vez que são assumidas como divergentes. Ou seja, o saber em detrimento do fazer, o teórico em detrimento da prática, o científico em detrimento do técnico". Nesse processo, os conteúdos ou a teoria são entendidos como de responsabilidades das disciplinas que compõem a matriz curricular do curso de licenciatura, enquanto a prática fica quase exclusivamente a cargo dos estágios obrigatórios ou de disciplinas teórico-práticas que contemplam a formação pedagógica. É importante destacar, todavia, que a problematização sobre a prática profissional docente, o contexto escolar, os processos de ensinar e de aprender, as especificidades dos estudantes e as condições de trabalho do professor não devem ser uma preocupação apenas de um programa de iniciação à docência ou do estágio obrigatório - ou ainda de algumas poucas unidades da matriz curricular -, mas de todo o curso de licenciatura, seja em suas disciplinas de conhecimento específico, seja naquelas de conhecimento pedagógico geral ou de conhecimento pedagógico do conteúdo. Desta forma, o estudante não participaria de um programa de formação ou ingressaria no estágio sem saber como nele - ou a partir dele - agir, mas teria condições de dar continuidade e ampliar um processo que já estaria em desenvolvimento desde o início de seu curso de formação inicial.

Ao contemplar um número significativo de estudantes do curso, o PIBID pode apresentar-se como o espaço híbrido ou terceiro espaço de formação, como defendido por 
Zeichner (2010), com potencial de contribuir para a articulação entre os saberes teóricopráticos adquiridos nas diferentes disciplinas do curso de licenciatura, a prática profissional e o cotidiano escolar, em suas diferentes dimensões. Isso contribuiria não apenas para a formação e atuação dos estudantes e dos professores direta ou indiretamente envolvidos, mas também articularia e estreitaria a parceria entre escola e universidade no processo de iniciação à docência.

A partir da análise dos dados, alguns aspectos foram também apontados como limitantes pelos participantes. Um deles se refere ao apoio da universidade às atividades realizadas no âmbito do Programa. Em algumas situações, há contrapartida da universidade para a realização dos trabalhos desenvolvidos e para a socialização desses trabalhos; todavia, relatos de alguns dos participantes entrevistados demonstram a desvalorização do PIBID por parte de muitos dos professores que não atuam no Projeto. Para esses participantes, tal desvalorização está associada, principalmente, ao fato de o Programa não ter por objetivo principal o desenvolvimento de pesquisas e por estar vinculado a cursos de licenciatura, historicamente desvalorizados nas instituições universitárias.

Tendo em vista esses aspectos, consideramos que, para que as atividades relacionadas ao Programa sejam desenvolvidas de maneira satisfatória, não apenas os participantes do Projeto devem com ele se envolver, mas também toda a comunidade acadêmica, no sentido de vincular o PIBID não somente a um curso de licenciatura, mas, especialmente, a um projeto e uma política de formação docente da universidade. Assim, não apenas este Programa passará a ser mais valorizado dentro das instituições de ensino superior, mas, igualmente, os cursos de formação de professores. Da mesma forma, é preciso que os professores da educação básica, as escolas e, de uma maneira mais ampla, as redes de ensino se comprometam e se envolvam efetivamente com o PIBID e com sua proposta de formação. Aliás, a participação dos professores e da escola e o papel das redes de ensino para o desenvolvimento do Programa foi um dos principais aspectos discutidos pelos participantes do estudo.

A análise dos dados nos permitiu observar que não apenas a formação dos bolsistas de iniciação à docência é favorecida e enriquecida pelo PIBID mas, igualmente, a formação e a prática dos professores da universidade e supervisores da educação básica. Tal contribuição favorece, da mesma forma, a aproximação desses professores com a universidade e dessa com a escola e seus profissionais, numa perspectiva de formação recíproca, colaborativa e contínua que pode possibilitar, como consequência, intervenções na própria prática educativa.

Todavia, se é verdade que o PIBID depende da atuação dos professores supervisores como coformadores e coprotagonistas - juntamente dos professores coordenadores e

RIAEE - Revista Ibero-Americana de Estudos em Educação, Araraquara, v. 16, n. 4, p. 2509-2538, out./dez. 2021. e-ISSN: 1982-5587 
colaboradores - no momento de planejamento, desenvolvimento e avaliação das atividades de iniciação e de formação para a docência, também é verdadeiro o fato de que a maioria desses professores se encontra muitas vezes em situações de trabalho desfavoráveis, que dificultam essa atuação de maneira satisfatória. Sobre esse aspecto, a análise dos dados nos permitiu observar que muitos dos supervisores, incluindo-se aqueles que, segundo os participantes entrevistados, apresentam-se comprometidos com os objetivos de formação do PIBID, trabalham em tempo integral - muitas vezes em mais de uma escola -, com pouco tempo para o planejamento de suas atividades, o que, de certa forma, pode prejudicar sua participação de maneira mais diretiva na orientação dos alunos da licenciatura e nas atividades relacionadas ao PIBID. Assim, faz-se necessário que tais questões sejam ponderadas no momento de avaliação do PIBID e da participação dos que nele se encontram envolvidos, a fim de que não nos percamos na ingenuidade de responsabilizar ou culpabilizar apenas os professores da educação básica pelo sucesso ou fracasso do processo de integração dos bolsistas de iniciação à docência no contexto escolar.

Outrossim, é preciso considerar o fato de que, no âmbito do PIBID, as escolas e seus professores são considerados corresponsáveis pela formação prática dos futuros professores sem que tenham, todavia, tido a oportunidade de discutir essa questão de forma abrangente. Até então, muitos professores da educação básica não tinham reconhecimento de sua participação efetiva nesse processo de formação; seu papel se restringia, na maioria dos casos, em ceder o espaço da sua sala de aula para os estagiários para que ali pudessem fazer suas observações e dar sua aula de regência, em cumprimento às exigências do curso de formação. Com o PIBID, é solicitado a estes professores que compartilhem o processo formativo dos futuros professores, sem que ao menos tenham sido ouvidos nesse processo e sem que houvesse, em alguns casos, formação e maiores esclarecimentos a esse respeito.

Por esse motivo, são necessárias ações formativas para que os docentes compreendam e possam atuar de maneira efetiva como coformadores de futuros professores em suas primeiras inserções nas escolas. Trata-se, portanto, da necessidade de se consolidar, no âmbito do Programa e por meio da parceria entre escola e universidade, ações de "formação de formadores", nas quais membros internos e externos ao Programa - supervisores, coordenadores de área, colaboradores, coordenadores de gestão e institucional, núcleos regionais e secretarias de ensino e equipes gestoras das escolas -, estejam envolvidos. Tais ações contribuirão não apenas para uma melhor definição sobre o papel dos supervisores e dos demais sujeitos no Programa, mas, igualmente, para uma melhor atuação desses profissionais no processo de formação dos licenciandos. 
Da mesma forma, faz-se necessário que as redes de ensino e, mais especificamente, o poder público adote o PIBID não apenas como mais um programa pontual, de governo, mas como uma política abrangente, de Estado, voltada à formação docente, garantindo as condições necessárias de trabalho e de carreira que permitam a esses profissionais destinar parte de sua atividade profissional para essa tarefa particularmente importante na formação prática dos futuros professores. Como afirma França (2006), é preciso delimitar com maior clareza que tarefas são esperadas desse profissional e em quais condições elas são possíveis de serem realizadas.

Precisamos levar em consideração todos esses aspectos, afinal, pensar em uma política de formação de professores implica pensar, com a mesma seriedade, nas condições objetivas para que as iniciativas desenvolvidas se materializem no âmbito da prática. Transferir à escola e aos seus profissionais responsabilidades na formação de futuros professores sem que as relações entre o ensino superior e a educação básica sejam de fato estabelecidas e sem que essas condições sejam garantidas pode configurar-se como um fator restritivo a mais a ser enfrentado no processo formativo.

\section{REFERÊNCIAS}

BRASIL. Portaria Gab n. 45, de 12 de março de 2018. Dispõe sobre a concessão de bolsas e o regime de colaboração no Programa de Residência Pedagógica e no Programa Institucional de Bolsa de Iniciação à Docência. Brasília, DF, 15 mar. 2018. Disponível em: https://www.in.gov.br/materia/-/asset_publisher/Kujrw0TZC2Mb/content/id/6628725/do12018-03-15-portaria-n-45-de-12-de-marco-de-2018-6628721. Acesso em: 21 maio 2019.

BRASIL. Portaria n. 260, de 30 de dezembro de 2010. Aprova as normas do Programa Institucional de Bolsa de Iniciação à Docência - PIBID. Brasília, DF, 3 jan. 2011. Disponível em: https://www.legisweb.com.br/legislacao/?id=224343. Acesso em: 22 ago. 2012.

BRASIL. Portaria n. 96, de 18 de julho de 2013. Regulamenta o Programa Institucional de Bolsa de Iniciação à Docência (PIBID). Brasília, DF, 23 jul. 2013. Disponível em: https://www.in.gov.br/materia/-/asset publisher/Kujrw0TZC2Mb/content/id/30798135/do12013-07-23-portaria-n-96-de-18-de-julho-de-2013-30798127. Acesso em: 20 ago. 2013.

CANDAU, V. M. F. A formação continuada de professores: tendências atuais. In: REALI, A. M. M. R.; MIZUKAMI, M. G. N. (org.). Formação de professores: tendências atuais. São Carlos: EDUFSCar, 1996.

FELÍCIO, H. M. S. O PIBID como "terceiro espaço" de formação inicial de professores. Rev. Diálogo Educ., Curitiba, v. 14, n. 42, p. 415-434, maio/ago. 2014.

FERREIRA, A. C. O trabalho colaborativo como ferramenta e contexto para o desenvolvimento profissional: compartilhando experiências. In: NACARATO, A. M.;

RIAEE - Revista Ibero-Americana de Estudos em Educação, Araraquara, v. 16, n. 4, p. 2509-2538, out./dez. 2021. e-ISSN: 1982-5587 
PAIVA, M. A. V. (org.). A formação do professor que ensina Matemática: perspectivas e pesquisas. Belo Horizonte: Autêntica, 2006.

FRANÇA, D. S. Formação de Professores: a parceria escola-universidade e os estágios de ensino. UNIrevista, São Leopoldo, v. 1, n. 2, p. 1-10, abr. 2006.

GARCÍA, C. M. O professor iniciante, a prática pedagógica e o sentido da experiência. Revista Brasileira de Pesquisa sobre Formação Docente, Belo Horizonte, v. 2, n. 3, p. 11 49, ago./dez. 2010.

GATTI, B. A. Formação de professores e carreira: problemas e movimentos de renovação. Campinas: Autores Associados, 2000.

GATTI, B. A.; BARRETO, E. S. S. Professores do Brasil: impasses e desafios. Brasília: UNESCO, 2009.

GATTI, B. A. et al. Um estudo avaliativo do Programa Institucional de Bolsa de Iniciação à Docência (PIBID). São Paulo: FCC/SEP, 2014.

LESSARD, C. Gobernabilidad y políticas educativas: sus efectos sobre el trabajo docente. La perspectiva canadiense. In: ANDRADE OLIVEIRA, D. et al. Políticas educativas y territórios: modelos de articulación entre niveles de gobierno. Buenos Aires: UNESCOIIPE, 2010. p. 67-112.

LIBÂNEO, J. C. As políticas de formação de professores no contexto da reforma universitária: das políticas educativas para as políticas da educação. Revista Profissão Docente, Uberaba, v. 4, n. 12, p. 33- 55, set./dez. 2005.

LÜDKE, M.; ANDRÉ, M. E. D. A. Pesquisa em educação: abordagens qualitativas. 2. ed. Rio de Janeiro: E.P.U., 2014.

MANCEBO, D.; MAUES, O.; CHAVES, V. L. J. Crise e reforma do Estado e da Universidade Brasileira: implicações para o trabalho docente. Educar em Revista, Curitiba, v. 22, n. 28, p. 37-53, 2006.

NÓVOA, A. Professores: imagens do futuro presente. Lisboa: Educa, 2009.

OLIVEIRA, S. A.; REZENDE, D. P. L.; CARNEIRO, R. F. Processos formativos de professores supervisores no âmbito do PIBID: sentidos atribuídos às atividades experienciadas na universidade e na escola. Revista Ibero-Americana de Estudos em Educação, Araraquara, v. 16, n. esp. 1, p. 982-998, mar. 2021.

REALI, A. M. M. R; TANCREDI, R. M. S. P. A importância do que aprende na escola: análise de uma experiência de parceria escola-famílias e universidade-escola. Paideia, Ribeirão Preto, v. 15, n. 31, p. 239-247, 2005.

SHULMAN, L. Conocimiento y enseñanza: fundamentos de la Nueva reforma. Revista de currículum y formación del profesorado, Granada, v. 9, n. 2, 2005. 
TANCREDI, R. M. S. P. Políticas públicas de formação de professores: o PIBID em foco. (Conferência). Revista EXITUS, v. 3, n. 1, jan./jun. 2013.

TARDIF, M. Saberes docentes e formação profissional. 13. ed. Petrópolis: Vozes, 2012.

TAUCHEN, G.; DEVECHIV, C. P. V. Interações entre a universidade e a educação básica. Revista Ibero-americana de Estudos em Educação, Araraquara, v. 11, n. esp. 1, p. 527 538, 2016. DOI: https://doi.org/10.21723/RIAEE.v11.esp.1.p527

ZEICHNER, K. Repensando as conexões entre a formação na universidade e as experiências de campo na formação de professores em faculdades e universidades. Educação, Santa Maria, v. 35, n. 3, p. 479-504, set./dez. 2010.

\section{Como referenciar este artigo}

DEIMLING, N. N. M.; REALI, A. M. M. R. Possibilidades e desafios do PIBID para o estreitamento da relação entre escola e universidade. Revista Ibero-Americana de Estudos em Educação, Araraquara, v. 16, n. 4, p. 2509-2538, out./dez. 2021. e-ISSN: 1982-5587. DOI: https://doi.org/10.21723/riaee.v16i4.14300

Submetido em: $21 / 07 / 2021$

Revisões requeridas em: 20/08/2021

Aprovado em: 25/09/2021

Publicado em: 21/10/2021 